\title{
Lack of Serum Oligoclonal Antibody Responses to Chlamydophila pneumoniae in Multiple Sclerosis
}

\author{
J. Parratt \\ Department of Medicine, Gold Coast Hospital, Southport, Australia
}

Dear Sir,

Dr. Chapman and colleagues [1] demonstrated patients with multiple sclerosis (MS) do not exhibit serum oligoclonal antibody responses to Chlamydophila pneumoniae antigens using Western blotting (WB). The authors concluded that systemic C. pneumoniae infection is not associated with MS.

Although one would expect reactive serum oligoclonal bands to C. pneumoniae, should the bacterium be present and pathogenic, WB may not be the most sensitive measurement of $C$. pneumoniae antibody responses [2]. This may explain the discrepancy between the lower frequency of serum antibody detected by WB in this study compared to the authors' previous study using the microimmunofluorescence (MIF) test [3]. Several studies have confirmed a high prevalence of $C$. pneumoniae $\mathrm{IgG}$ antibodies in both MS patients and controls using MIF [3]. This is expected given the high frequency of antibodies in western populations, in general [4].

Certain surface $C$. pneumoniae epitopes, particularly the major outer membrane protein (MOMP), are prone to denaturing and cannot be detected using WB [2]. MIF tests and commercially available enzyme-linked immunosorbent assays (ELISA) use whole organisms as the antigenic target with struc- tural conservation of immunogenic proteins such as MOMP. Although the antigenicity of each C. pneumoniae surface protein is not well characterized, a broader range of antibody responses would be detected using these tests.

Presumably, to increase specificity, the authors used WB. Certainly, isolated positive results using MIF or ELISA are difficult to interpret because they may represent acute, chronic or previous infection. $C$. pneumoniae antibody testing in this way is discouraged [5]. However, it is difficult to exclude systemic $C$. pneumoniae infection in patients with MS using antibody testing alone, considering the technical difficulties with WB. To do this, antigen-specific testing of sera is required, either to detect free antigen or immune complexes, a method used in studies of cardiovascular disease [6].

C. pneumoniae is a common cause of respiratory infection in western populations and may become chronic. The majority of serological studies do not support $C$. pneumoniae as an aetiological agent in MS. However, the rate of systemic infection should be characterised, using antigen-specific methods, as chronic bacterial infection in susceptible MS patients may exacerbate the autoimmune pathogenesis.

\section{References}

1 Chapman MD, Hartley JC, Furrows SJ, Ridgeway GL, Thompson EJ, Church AJ, et al: Lack of serum oligoclonal antibody responses to Chlamydophila pneumoniae in multiple sclerosis. Eur Neurol 2005;53:81-83.

2 Wolf K, Fischer E, Mead D, Zhong G, Peeling $\mathrm{R}$, Whitmire $\mathrm{B}$, et al: Chlamydia pneumoniae major outer membrane protein is a surface-exposed antigen that elicits antibodies primarily directed against conformation-dependent determinants. Infect Immun 2001;69:30823091.

3 Furrows SJ, Hartley JC, Bell J, Silver N, Losseff $\mathrm{N}$, Stevenson S, et al: Chlamydophila pneumoniae infection of the central nervous system in patients with multiple sclerosis. J Neurol Neurosurg Psychiatry 2004;75:152-154.

4 Kuo CC, Jackson LA, Campbell LA, Grayston JT: Chlamydia pneumoniae (TWAR). Clin Microbiol Rev 1995;8:451-461.

5 Dowell SF, Peeling RW, Boman J, Carlone GM, Fields BS, Guarner J, et al: Standardizing Chlamydia pneumoniae assays: recommendations from the Centers for Disease Control and Prevention (USA) and the Laboratory Centre for Disease Control (Canada). Clin Infect Dis 2001;33:492-503.

6 Tavendale R, Parratt D, Pringle SD, A'Brook $\mathrm{R}$, Tunstall-Pedoe H: Serological markers of Chlamydia pneumoniae infection in men and women and subsequent coronary events. The Scottish Heart Health Study Cohort. Eur Heart J 2002;23:301-307.

\section{KARGER}

Fax +4161306 1234 E-Mail karger@karger.ch www.karger.com www.karger.com/ene
Dr. John Parratt, MBChB

Department of Medicine

Gold Coast Hospital

Southport, Queensland (Australia)

E-Mail jparratt@bigpond.net.au 


\section{Reply}

M.D. Chapman

Department of Neuroimmunology, Institute of Neurology, University College London, London, UK

The two complementary studies $[1,2]$ were performed simultaneously on the same cohorts. Seropositivity was determined by WB [1] and ELISA on all samples, positives on ELISA being followed up with MIF [2]. CSF samples were analysed by PCR and culture [2] to replicate the work of Sriram [3] whilst all paired samples were analysed by IEF for oligoclonal IgG [1].

We agree with Dr. Parratt that MIF is the diagnostic gold standard but it cannot distinguish between high and low affinity antibody and whether that antibody response is polyclonal or oligoclonal. When the hypothesis is that $C$. pneumoniae may be an infectious cause of MS, these are important considerations. Our original intention was to follow up serum positives with
IEF of paired samples, to investigate the clonality of serum and CSF, followed by antigen immunoblotting and probing with thiocyanate to investigate affinity. However, as both studies $[1,2]$ reported identical incidences of seropositivity by all methods in MS patients and controls it was felt unnecessary to do this.

\section{References}

1 Chapman MD, Hartley JC, Furrows SJ, Ridgway GL, Thompson EJ, Church AJ, Candler PM, Giovannoni G: Lack of serum oligoclonal antibody responses to Chlamydophila pneumoniae in multiple sclerosis. Eur Neurol 2005; 53:81-83.

2 Furrows SJ, Hartley JC, Bell J, Silver N, Losseff N, Stevenson S, Chapman M, Thompson EJ, Ridgway GL, Giovannoni G: Chlamydophila pneumoniae infection of the central nervous system in patients with multiple sclerosis. J Neurol Neurosurg Psychiatry 2004;75:152154.

3 Sriram S, Stratton CW, Yao S, Tharp A, Ding L, Bannan JD, Mitchell WM: Chlamydia pneumoniae infection of the central nervous system in multiple sclerosis. Ann Neurol 1999; 46:6-14.

M.D. Chapman

Department of Neuroimmunology

Institute of Neurology

University College London

Queen Square, London, WC1N 3BG (UK)

Tel. +44 207837 3611/ext. 4207

Fax +44 2078376553

E-Mail m.chapman@ion.ucl.ac.uk 